\title{
Clean or Dilapidated Style: The Controversy Between Aesthetic Standards of Seal Engraving Since the Ming and Qing Dynasties
}

\author{
Kaiwei Zhang ${ }^{1, *}$ \\ ${ }^{1}$ Arts College of Sichuan University, Chengdu, Sichuan, China \\ *Corresponding author. Email: 308613928@qq.com

\begin{abstract}
Since the Ming and Qing Dynasties, the art of seal engraving has become a literati style and the aesthetic standards of seal engraving have become controversial and been divided into clean style and dilapidated style. Taking the criticism and controversy of clean style and dilapidated style in seal engraving theory as the clue, this paper aims to explore the development of seal engraving art in the controversy between the two aesthetic standards since the Ming and Qing dynasties, reveal the inner development path of modern seal engraving art, and thus have a new understanding of the development history of seal engraving since the Ming and Qing Dynasties.
\end{abstract}

Keywords: Standards of seal engraving, Clean style, Dilapidated style, Development of seal engraving.

\section{INTRODUCTION}

In the Yuan and Ming Dynasties, the limitations in seal materials were broken through, which makes it available to "engrave seal for private use'", and the art of seal engraving became a literati style flourished. Indeed as Zhou Lianggong said, "the way of seal engraving was founded by Wen Peng and then abided by later generations and generalized all over the world". ${ }^{1}$ Since Wen Peng's age in the Ming Dynasty, the art of seal engraving had achieved unprecedented development. The theories, works and famous artists of seal engraving have come forth in riotous profusion for 500 years. Styles and schools of seal engraving are roughly divided into two distinct core aesthetic standards: clean style and dilapidated style. As two main systems of the seal engraving, the two styles have gone through several representative stages in their development, along with criticism and controversy.

1. [Qing] Zhou Lianggong. The Biography of Seal Engravers". "Selected Papers of Seal Studies in Past Dynasties" edited by Han Tianheng. Xiling Seal Engraver's Society Publishing House. Aug., 1999, p157.

\section{THE TRADITION OF SEAL ENGRAVING IN CLEAN STYLE AND THE APPRECIATION OF "NATURAL DILAPIDATED STYLE"}

"Seal is a token". As a voucher of credit, seal has solemn and formal significance. Therefore, seal script has always been used as the main font of text on seal and developed under the orthodox and gentle aesthetic standards of traditional Confucianism in China. Till the late Ming Dynasty, Wen Peng and $\mathrm{He}$ Zhen, the representative of literati seal engraving, engraved seals on stone and thus created cracking and dilapidated effect, which gave rise to a new aesthetic taste. Just as Bai Qianshen stated, "He Zhen made full use of the texture of stone and engraved seal in more natural and smooth knife skill. The dilapidated effect caused in this knife skill adds some simple and ancient meaning to his seal". ${ }^{2}$ The emergence of this effect directly led to seal engravers'

2. [USA] Bai Qianshen. FU SHAN'S WORLD: The Transformation of Chinese Calligraphy in the Seventeenth Century. SDX Joint Publishing Company. Sep., 2015, p64. 
appreciation for dilapidated beauty in the late Ming Dynasty.

In the late Ming Dynasty, the trend of collecting and imitating ancient seals gradually prevailed. For example, Gu Congde's "Collection of Seal Patterns (印薮)" (see "Figure 1") collected more than 1,700 ancient copper jade seals. Shen Defu once said, "Since the publication of Gu Congde's "Collection of Seal Patterns", and the Han seals were all gathered together, the later scholars began to know the wonders of ancient seals." ${ }^{3}$ At the time, a large number of ancient seals were seriously weathered, corroded and dilapidated and showed mottled or broken appearance due to the material, long age and other factors. Seal engravers in the Ming Dynasty imitating ancient seal also began to imitate this "trace of age", and appreciate this natural dilapidated style and natural ancient taste.

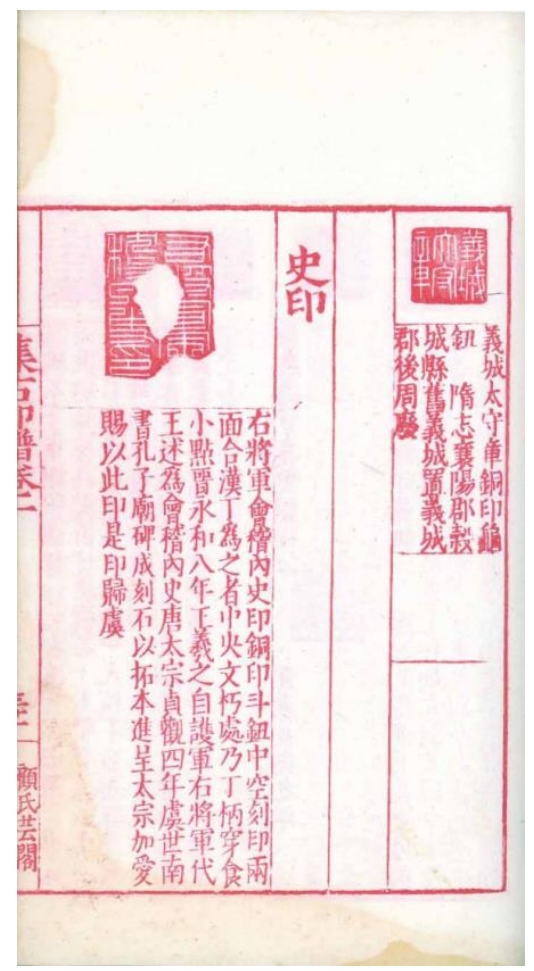

Figure 1 Part of the inside page of red seal copy of Yun Ge in the "Collection of Seal Patterns" published in the third year of Wanli period and collected by Xiling Seal Engraver's Society.

Shen Ye in the late Ming Dynasty once said, "every time I get a spotted stone with veins and defects that cannot be used for engraving, I will be especially excited as an ancient taste can be naturally created by engraving on the basis of the

3. [Ming] Shen Defu. An Unofficial History of WanLi Period. Chung Hwa Book Co., Feb., 1959, p659. deep and shallow parts and the rusted and eroded base"4. To pursue this "natural dilapidated" ancient taste, it had been not enough in creation method to merely use knife skills in addition to using stone. For example, Shen Ye once also recorded, "After a stone seal is engraved, Wen Peng often places it in a box and let boy shake it all day long; Chen Taixue often throws stone seal on the ground for many times till it peels off and appears ancient taste." 5 This aesthetic trend taking incompleteness as the ancient taste continued to ferment and the taking method also broken through the limit of ancient seal and began to learn from the erosion of ancient stele. As recorded in the "Seal Engraving Systems in Ancient and Modern Times", Su Xiaomin in Ming Dynasty wanted to engrave on stone drum and Ji Zha's rule of stele engraving by using stylus pen. His seal did not abide by the written law of imitating seal but pursue following ancient theories and rubbing from stone inscription so that the seal showed the trace of erosion. Although his seal did not conform to the impression of seal since Qin and Han Dynasties, it adopted the text with white background on ancient bronze ware, aiming to show the ancient taste. He can be called an outstanding person in the study of seal." ${ }^{6}$ It can be said that he initiatively raised the trend of "seeking seal beyond seal".

\section{THE TRANSFORMATION FROM "NATURAL DILAPIDATED STYLE" TO "NATURALLY DILAPIDATED STYLE"}

It can be said that seal engravers in the late Ming Dynasty made many attempts to achieve the dilapidated taste due to appreciation. However, this pursuit was against the tradition, and thus it was unavoidable to be criticized by people at that time. For example, Gan Yang once questioned, "Ancient seal may also pursue looking tidy; then, how can we say that it pretended to be dilapidated? But over a long time, it may be damaged or not clear due to weathering and erosion. If the seal is intentionally

4. [Ming] Shen Ye. About Seals. "Selected Papers of Seal Studies in Past Dynasties" edited by Han Tianheng. Xiling Seal Engraver's Society Publishing House. Aug., 1999, Vol.A, p65.

5. [Ming] Shen Ye. About Seals. "Selected Papers of Seal Studies in Past Dynasties" edited by Han Tianheng. Xiling Seal Engraver's Society Publishing House. Aug., 1999, Vol.A, p64.

6. [Ming] Sun Guangzu. Seal Engraving Sysems in Ancient and Modern Times. "Selected Papers of Seal Studies in Past Dynasties" edited by Han Tianheng. Xiling Seal Engraver's Society Publishing House. Aug., 1999. Vol.A, p282. 
dilapidated to imitate ancient seal but not abide by the rules of words and engraving of ancient seal, will the ancient taste be affected?" 7 Yang Shixiu also criticized, "or the material is intact and knocked to form the seal pattern. This process is called making but surprising to common people. "8

In the late Qing Dynasty, Zhao Zhiqian, a master seal engraver who merged Zhejiang and Anhui schools, also advocated that the beauty of "Han bronze seals don't lie in the mottled but the vigorous feature" ${ }^{9}$, which had a wide influence. Zhao Zhiqian believed that a good engraving did not need to be dilapidated, while $\mathrm{Wu}$ Changshuo promoted his concept of "seeking seal beyond seal" but did not agree with his attitude to the dilapidated and mottled beauty. Hence in practice of seal engraving, the transformation of dilapidated aesthetic standard was realized and the opportunity for the transformation is to take the method of clay impression of seal.

In ancient documents, there are many records about clay impression of seal and related inspection system. However, when the relics of ancient clay impression of seal were found in Sichuan and Shandong in the Qing Dynasty, it was difficult for scholars studying the inscriptions on ancient bronzes and stone tablets to determine it for a while but mistakenly think that "seals in Han Dynasty are the model". ${ }^{10}$ Zhao Zhiqian also held this opinion in the "Supplementary to the Records of Searching Steles in Huanyu (补寰宇访碑录)". Later in Shaanxi and Shandong, a large number of clay impressions of seal were also discovered. In the first year of Xianfeng period (1851), Chen Jieqi collected the clay impressions of seal in the "Collection of $\mathrm{Fu}$ Zhai Seals" for the first time, and mentioned the opinion of impressing clay in seal in the

7. [Ming] Gan Yang. Theory of the Collection of Seals. "Selected Papers of Seal Studies in Past Dynasties" edited by Han Tianheng. Xiling Seal Engraver's Society Publishing House. Aug., 1999. Vol.A, p83.

8. [Ming] Yang Shixiu. Basic Law of Seal Engraving. "Selected Papers of Seal Studies in Past Dynasties" edited by Han Tianheng. Xiling Seal Engraver's Society Publishing House. Aug., 1999. Vol.A, p92.

9. [Qing] Zhao Zhiqian. The margin of "Seal of He Chuanzhu". "Chronological collection of seals of Zhao Zhiqian" written by Qi Yuan. Jiangxi Fine Arts Publishing House. 2008, p20.

10. [Qing] Wu Rongguang. Jun Qing Guan Inscriptions on Ancient Bronzes and Stone Tablets. Compilation Committee of the "Continuous Repair of the Si Ku Quan Shu (续修四库全书 )", Book No. 902 of the Continued Repair of the Si Ku Quan Shu: History - Inscriptions on Ancient Bronzes and Stone Tablets". Shanghai Ancient Books Publishing House, 1996, Vol.5, p137. correspondence with $\mathrm{Wu}$ Yun, the contemporary collector of inscriptions on ancient bronzes and stone tablets.

Precisely, Wu Changshuo's dilapidated style was started from taking the method of clay impression. At that time, he was a private teacher of $\mathrm{Wu}$ Yun's family. Wu Yun collected a large number of ancient bronze wares, books of stone inscriptions, and seal patterns of famous seal engravers. $\mathrm{Wu}$ Changshuo often observed and learnt from them, including the excellent rubbings of clay impression in the "Collection of Fu Zhai Seals". Wu Changshuo imitated the ancient practice of impressing clay in seal ("Figure 2") and was inspired from it, "the knife should be sharp and clumsy, and the seal should have ancient appearance and virtual spirit. The clay impression learners should better follow this rule." 11

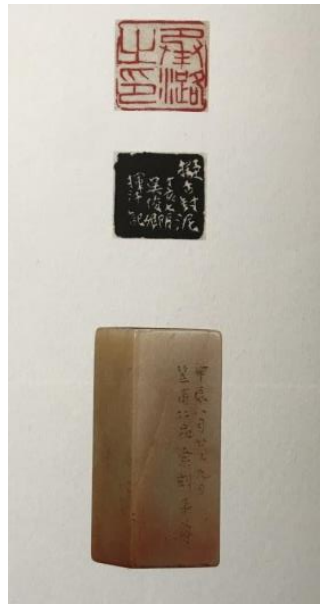

Figure 2 Wu Changshuo's "Seal of Cheng Lu" collected in Juntao Art Academy; imitating the ancient clay impression of seal; recorded by $\mathrm{Wu}$ Junqing in July in the year of Dinghai.

"The spirit of casting and chiseling is separated from that in the Qin and Han dynasties and embodies in the clay impression." ${ }^{12}$ As for the origin of seal in Qin and Han dynasties, how to understand the Qin and Han Dynasties? Wu Changshuo got the answer from the clay impression of seal. Just as Mr. Hou Kaijia concluded, "Wu Changshuo's use of clay impression for reference is reflected in two points. First, the margin of seal is dilapidated so that the margin is integrated with the

11. [Qing] Wu Changshuo. The margin of "Long Fou" seal. "Selected Papers of Seal Studies in Past Dynasties" edited by Han Tianheng. Xiling Seal Engraver's Society Publishing House. Aug., 1999. Vol.B, p770.

12. Wu Dongmai. Wu Changshuo's Talking about Art. People's Fine Arts Publishing House, 1993, p133. 
inscription. Second, he changed the tradition of using square small seal script for making whitecharacter seal and using small seal script for making red-character seal and made the characters of red and white-character seals forming a uniform character." ${ }^{13}$ Inspired by clay impression of seal, the dilapidated effect created by $\mathrm{Wu}$ Changshuo is not created by shaking or throwing but by intentional intervention. Although he clearly knew that this effect was acquired effect, the special beauty attracted him to make exploration. In the Qing Dynasty, Wu Changshuo was not only a painter but also a calligrapher and seal engraver. Just as reflected in his poem, "Genuine will is embodied in the poetry, calligraphy and painting. The key point is to make an integrated use of them." ${ }^{14} \mathrm{He}$ integrated the concepts of painting, calligraphy and seal engraving together, realizing the change from "natural style" to "naturally created style" in the aesthetic standard of dilapidated style of seal engraving.

Wu Changshuo, relying on his creative freehand style and leadership as the first president of Xiling Seal Engraver's Society, drove a group of people to engrave in this creative and intentionally dilapidated style so that this style became fashionable all over the country at that time. Qi Baishi, Zhao Gu'ni, Deng Sanmu, Lai Chusheng, Wang Yong and et al., including modern seal engraving, were all affected by $\mathrm{Wu}$ Changshuo. Japanese calligraphy and seal engravers Nishiku Minghe, Nagao Yushan, and Tsuenlu Kawai were all affected by his style. Among them, Tsuenlu Kawai even became a disciple of $\mathrm{Wu}$ Changshuo. He traveled to China several times, devoted himself to Wu Changshuo's seal style and joined Xiling Seal Engraver's Society ${ }^{15}$. He also introduced $\mathrm{Wu}$ Changshuo to the seal engraving circle in Japan, which raised a great influence. Just as Wang Senran wrote, "After Mr. Wu Changshuo becoming famous, his seal engraving style was fashionable both at home and abroad in the past 30 to 40 years. Even young seal engravers would imitate his

13. Hou Kaijia. A Collection of Papers about the History of Calligraphy. Shanghai Ancient Books Publishing House, Aug., 2017, p217.

14. [Qing] Wu Changshuo. Poem of "Seal Engraving". "Selected Papers of Seal Studies in Past Dynasties" edited by Han Tianheng. Xiling Seal Engraver's Society Publishing House. Aug., 1999, Vol.B, p895.

15. Sha Menghai (author), Chen Zhenlian (introduction). History of Seal Studies. Shanghai Calligraphy and Painting Publishing House. Jan., 2017, p146. style." ${ }^{16}$ Hence, Wu Changshuo's seal engraving style successfully led the development of seal engraving in modern history.

\section{CONFRONTATION AND DEVELOPMENT OF CLEAN STANDARD AND DILAPIDATED STANDARD}

Before or after Wu Changshuo became wellknown, he was not recognized by everyone and his dilapidated seal engraving style was always controversial. As recorded in the Author's Preface of "Stored Seals of Fou Lu", "Every time I engrave, if the seal engraved is alike in spirit, it is regarded that there is a progress in skill. But if I send it to others as a gift, it will inevitably raise criticism."17 The criticizer also includes Wu Changshuo's friends, such as Zheng Wenzhuo who obtained many seals from $\mathrm{Wu}$ Changshuo but nearly derogatorily evaluated that "It's just a stone engraved by my friend. The ancient taste is obtained by deliberate rubbing. Or the stone is intentionally dilapidated, lacking natural flavor. This is the limit of stone." ${ }^{18}$ Japanese Yuanshan Dayu regarded him as a "friend" for respecting his center-forward knife skill, but he also held negative attitude towards $\mathrm{Wu}$ Changshuo's dilapidated style. In his "About the Origin of Seal Engraving", Wu Changshuo was commented that "it is not to say that his seal engraving is inferior but the dilapidated margin is empty or adopts protruded font and looks rusted or corroded. In this way, the ancient taste is reflected but the decent law is not abided by." 19

Ma Heng as the second president of Xiling Seal Engraver's Society also opposed Wu Changshuo's dilapidated style. Just as he stated in "Talking about Seal Engraving", "His seal engraving method is biased. And after the seal engraving was completed, he would chisel the edge to form ancient dilapidated appearance". He even cited Cheng

16. Wang Senran. Mr. Wu Changshuo's Critical Biography". "Wu Changshuo's Talking about Art" edited by Wu Dongmai. People's Fine Arts Publishing House. 1993, p246.

17. [Qing] $\mathrm{Wu}$ Changshuo. Author's Preface of the "Stored Seals of Fou Lu". "Selected Papers of Seal Studies in Past Dynasties" edited by Han Tianheng. Xiling Seal Engraver's Society Publishing House. Aug., 1999, Vol.B, p626.

18. Chen Jvlai. About the Seals of An Chi Jing She. "Selected Essays on Contemporary Chinese Calligraphy Studies on Seal", Rong Bao Zhai Publishing House. 2010, p558.

19. [Japanese] Shigeki Matsumura. The Acceptance of Wu Changshuo's Calligraphy and Seal Engraving in Japan. Proceedings of International Seminar on Shanghai-Style Calligraphy. Shanghai Painting and Calligraphy Publishing House. Dec., 2008, p463. 
Yaotian's saying to criticize this "crafty deception" trend and also stated that "since the emerging of Wu Changshuo's dilapidated style, most seal engravers follow suit and this style is even taught in school. It is regarded that ancient taste is not manifested if the seal is not dilapidated and such seal cannot be called seal. Hence, it is urgent to correct this trend." 20 This indicates that Ma Heng extremely disagreed with the dilapidated style led by Wu Changshuo.

Among the voices opposing to Wu Changshuo's seal engraving standard, there was a clean style of seal engraving represented by Huang Mufu. Huang Mufu worshipped Zhao Zhiqian, and once said, "Among engravers of clean style of archaistic seal, Zhao Zhiqian is the winner and the remained cannot reach a tiny level of him."21 As stated in the margin of his "Ji Du Chang Nian (季度长年)" seal, "the erosion effect of seals in the Han Dynasty is created over years and years. Blind imitation with ludicrous effect is not wise" (see "Figure 3"). He disagreed with $\mathrm{Wu}$ Changshuo's opinion and thought that seal itself was not dilapidated and the dilapidated effect was created later. $\mathrm{He}$ also represented that seal engraving should follow the rule that "no seal is incomplete and no painting is unclean. Just like a jade, there is no disconnection but the ancient taste is shown. What amazing. ${ }^{22 "}$ About Huang Mufu, Fang Quqi said that "he advocates that in seal engraving, it is not needed to knock the edge, remove the corner and add trimmings, because a simple and plain work is more in good condition". ${ }^{23}$

20. Ma Heng. Talking about Seal Engraving. "Selected Papers of Seal Studies in Past Dynasties" edited by Han Tianheng. Xiling Seal Engraver's Society Publishing House. Aug., 1999, p415.

21. The margin of Huang Mufu's "Ji'an" Seal. "Selected Papers of Seal Studies in Past Dynasties" edited by Han Tianheng. Xiling Seal Engraver's Society Publishing House. Aug., 1999, p.778.

22. The margin of Huang Mufu's "Ouyang Yun Seal". "Selected Papers of Seal Studies in Past Dynasties" edited by Han Tianheng. Xiling Seal Engraver's Society Publishing House. Aug., 1999, p785.

23. Fang Quji. Collection of Seal Patterns of Seal Engraving Schools in Ming and Qing Dynasties. Shanghai Calligraphy and Painting Publishing House. 1980, p218
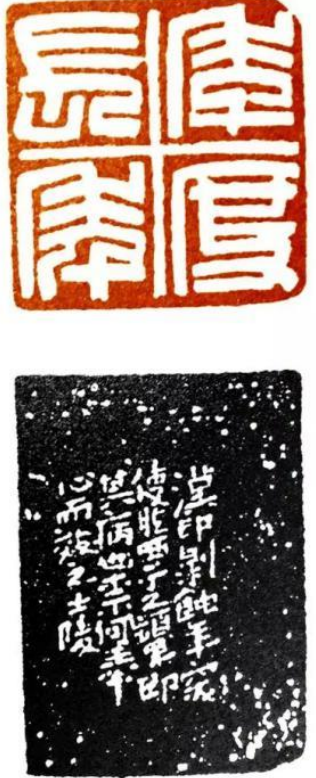

Figure 3 Huang Mufu's "Ji Du Chang Nian" seal, quoted from "The Collection of Huang Mufu's Seals" published by Xiling Seal Engraver's Society in 1993.

Although $\mathrm{Wu}$ Changshuo and Huang Mufu were in the same period of age, Huang Mufu's seal engraving style initially had little influence and was not concerned until Wu Changshuo's style was followed suit for long time so that the public was tired of the aesthetic standard. Hence, Huang Mufu became the master compared with $\mathrm{Wu}$ Changshuo. They were reputed as "two top masters with specific advantages" 24 . The two masters' engraving styles are as Chen Zhenlian said, "strong fashion and indifferent temperament, the coarse but not wild charm and the elegant but not weak sense, can be called two jades in modern seal engraving circle". ${ }^{25}$ Huang Mufu, as well as the subsequent Chen Jvlai and others advocating dexterous and thin seal engraving formed a school of clean and consolidated style.

\section{CONCLUSION}

Gombrich said, "The entire history of art development is not about the development in the technical proficiency, but about the changes in

24. Li Tong. Two Top Masters with Specific Advantages: A Comparative Study of Seal Engraving Art between Huang Mufu and Wu Changshuo. Journal of Ningbo Normal University (Social Science Edition). 1996 (04), p100p104 and p108.

25. Chen Zhenlian, "General Theory of Seal Engraving Art". Shanghai Calligraphy and Painting Publishing House. Aug., 2017. p154. 
concepts and requirements." ${ }^{26}$ As can be seen in the development of contemporary and modern seal engraving, there were criticism and controversy due to different aesthetic standards, and two different schools were formed. Although their opinions are different, both schools have seal engraving masters. Just as the modern Japanese seal engraving master Toan Kobayashi stated in "A Letter to Scholars of Xiling Seal Engraver's Society", Wu Rangzhi and $\mathrm{Wu}$ Changshuo are representatives of wilful and creative style, while Zhao Zhiqian and Huang Mufu are representatives of careful and conservative style, and "on the one hand, I admit that conservation and creation are contradictory; on the other hand, I believe that the two styles must be closely combined." ${ }^{27}$ Indeed, who is right and who is wrong cannot be simply judged. But what can be sure is that it is precisely such criticism and controversy as produced by different seal engraving standards that has promoted the development of seal engraving art since the Ming and Qing Dynasties.

\section{AUTHORS' CONTRIBUTIONS}

This paper is independently completed by Kaiwei Zhang.

\section{REFERENCES}

[1] [Qing Dynasty] Zhou Lianggong. The Biography of Seal Engravers". "Selected Papers of Seal Studies in Past Dynasties" edited by Han Tianheng. Xiling Seal Engraver's Society Publishing House. Aug., 1999, p157. (in Chinese)

[2] [USA] Bai Qianshen. FU SHAN'S WORLD: The Transformation of Chinese Calligraphy in the Seventeenth Century. SDX Joint Publishing Company. Sep., 2015, p64. (in Chinese)

[3] [Ming Dynasty] Shen Defu. An Unofficial History of WanLi Period. Chung Hwa Book Co., Feb., 1959, p659. (in Chinese)

[4] [Ming Dynasty] Shen Ye. About Seals. "Selected Papers of Seal Studies in Past Dynasties" edited by Han Tianheng. Xiling

26. Gombrich. "The Story of Art" translated by Fan Jingzhong. Beijing: SDX Joint Publishing Company. 1991, p1.

27. Toan Kobayashi. "A Letter to Scholars of Xiling Seal Engraver's Society" translated by Li Jing. http://www.360doc28.net/wxarticlenew/697895234.html
Seal Engraver's Society Publishing House. Aug., 1999, Vol.A, p65. (in Chinese)

[5] [Ming Dynasty] Shen Ye. About Seals. "Selected Papers of Seal Studies in Past Dynasties" edited by Han Tianheng. Xiling Seal Engraver's Society Publishing House. Aug., 1999, Vol.A, p64. (in Chinese)

[6] [Ming Dynasty] Sun Guangzu. Seal Engraving Sysems in Ancient and Modern Times. "Selected Papers of Seal Studies in Past Dynasties" edited by Han Tianheng. Xiling Seal Engraver's Society Publishing House. Aug., 1999. Vol.A, p282. (in Chinese)

[7] [Ming Dynasty] Gan Yang. Theory of the Collection of Seals. "Selected Papers of Seal Studies in Past Dynasties" edited by Han Tianheng. Xiling Seal Engraver's Society Publishing House. Aug., 1999. Vol.A, p83. (in Chinese)

[8] [Ming Dynasty] Yang Shixiu. Basic Law of Seal Engraving. "Selected Papers of Seal Studies in Past Dynasties" edited by Han Tianheng. Xiling Seal Engraver's Society Publishing House. Aug., 1999. Vol.A, p92. (in Chinese)

[9] [Qing Dynasty] Zhao Zhiqian. The margin of "Seal of He Chuanzhu". "Chronological collection of seals of Zhao Zhiqian" written by Qi Yuan. Jiangxi Fine Arts Publishing House. 2008, p20. (in Chinese)

[10] [Qing Dynasty] Wu Rongguang. Jun Qing Guan Inscriptions on Ancient Bronzes and Stone Tablets. Compilation Committee of the "Continuous Repair of the Si Ku Quan Shu (续 修四库全书)", Book No. 902 of the Continued Repair of the Si Ku Quan Shu: History . Inscriptions on Ancient Bronzes and Stone Tablets". Shanghai Ancient Books Publishing House, 1996, Vol.5, p137. (in Chinese)

[11] [Qing Dynasty] Wu Changshuo. The Margin of "Long Fou" seal. "Selected Papers of Seal Studies in Past Dynasties" edited by Han Tianheng. Xiling Seal Engraver's Society Publishing House. Aug., 1999. Vol.B, p770. (in Chinese)

[12] Wu Dongmai. Wu Changshuo's Talking about Art. People's Fine Arts Publishing House, 1993, p133. (in Chinese) 
[13] Hou Kaijia. A Collection of Papers about the History of Calligraphy. Shanghai Ancient Books Publishing House, Aug., 2017, p217. (in Chinese)

[14] [Qing Dynasty] Wu Changshuo. Poem of "Seal Engraving". "Selected Papers of Seal Studies in Past Dynasties" edited by Han Tianheng. Xiling Seal Engraver's Society Publishing House. Aug., 1999, Vol.B, p895. (in Chinese)

[15] Sha Menghai (author), Chen Zhenlian (introduction). History of Seal Studies. Shanghai Calligraphy and Painting Publishing House. Jan., 2017, p146. (in Chinese)

[16] Wang Senran. Mr. Wu Changshuo's Critical Biography". "Wu Changshuo's Talking about Art" edited by Wu Dongmai. People's Fine Arts Publishing House. 1993, p246. (in Chinese)

[17] [Qing Dynasty] Wu Changshuo. Author's Preface of the "Stored Seals of Fou Lu". "Selected Papers of Seal Studies in Past Dynasties" edited by Han Tianheng. Xiling Seal Engraver's Society Publishing House. Aug., 1999, Vol.B, p626. (in Chinese)

[18] Chen Jvlai. About the Seals of An Chi Jing She. "Selected Essays on Contemporary Chinese Calligraphy · Studies on Seal", Rong Bao Zhai Publishing House. 2010, p558. (in Chinese)

[19] [Japanese] Shigeki Matsumura. The Acceptance of Wu Changshuo's Calligraphy and Seal Engraving in Japan. Proceedings of International Seminar on Shanghai-Style Calligraphy. Shanghai Painting and Calligraphy Publishing House. Dec., 2008, p463. (in Chinese)

[20] Ma Heng. Talking about Seal Engraving. "Selected Papers of Seal Studies in Past Dynasties" edited by Han Tianheng. Xiling Seal Engraver's Society Publishing House. Aug., 1999, p415. (in Chinese)

[21] The Margin of Huang Mufu's "Ji'an" Seal. "Selected Papers of Seal Studies in Past Dynasties" edited by Han Tianheng. Xiling Seal Engraver's Society Publishing House. Aug., 1999, p.778. (in Chinese)

[22] The Margin of Huang Mufu's "Ouyang Yun Seal". "Selected Papers of Seal Studies in
Past Dynasties" edited by Han Tianheng. Xiling Seal Engraver's Society Publishing House. Aug., 1999, p785. (in Chinese)

[23] Fang Quji. Collection of Seal Patterns of Seal Engraving Schools in Ming and Qing Dynasties. Shanghai Calligraphy and Painting Publishing House. 1980, p218. (in Chinese)

[24] Li Tong. Two Top Masters with Specific Advantages: A Comparative Study of Seal Engraving Art between Huang Mufu and Wu Changshuo. Journal of Ningbo Normal University (Social Science Edition). 1996 (04), p100-p104 and p108. (in Chinese)

[25] Chen Zhenlian, "General Theory of Seal Engraving Art". Shanghai Calligraphy and Painting Publishing House. Aug., 2017. p154. (in Chinese)

[26] Gombrich. "The Story of Art" translated by Fan Jingzhong. Beijing: SDX Joint Publishing Company. 1991, p1. (in Chinese)

[27] Toan Kobayashi. "A Letter to Scholars of Xiling Seal Engraver's Society" translated by Li Jing. http://www.360doc28.net/wxarticlenew/69789 5234.html (in Chinese) 